13. Hallinan P. Factor structure and validity of the Alcohol Use Disorders Identification Test (AUDIT) in a sample of mentally disordered offenders / P. Hallinan, S. McGilloway, M. Dempster, \& M. Donnelly // The Journal of Forensic Psychiatry \& Psychology. - 2011, 22. - P. 586-602.

14. Hedlund J. The Michigan Alcoholism Screening Test (MAST): A comprehensive review / J. Hedlund \& B. Vieweg // Journal of Operational Psychiatry. - 1984, 15. - P. 55-64.

Eduard Krainikov, Ph.D., Assoc. Prof.

Eugeniy Prokopovich, Ph.D., Assoc. Prof.

Taras Shevchenko National University of Kyiv, Kyiv, Ukraine

Alona Balanyuk, psychologist

Kyiv, Ukraine
15. Heim E. Coping und Adaptivität: Gibt es geeignetes oder (1988, Vol. 38. - P. 8-18.

Надійшла до редколегії 22.06.19

\title{
FEATURES OF ADDICTIVE PERSONALITY
}

We surveyed 50 people between the ages of 18 and 25, most of respondents are college students. We used the following assessment tools: SMOL (abbreviated adaptation of MMPI), Heim's test for coping strategies, Mendelevich's methodic, Michigan Alcohol Test (MAST), Urgent Dependence Questionnaire in Shibko's adaptation. Respondents show some signs of predisposition, or even a clear presence of addictive behavior. Choosing a way to escape from reality was a cultural phenomenon, that is, the choice of an addictive agent is more dictated by advertising, public opinion, and art products. This data confirms the close direct relationship between alcohol dependence (according to MAST) and psychopathy - a correlation coefficient of 0.27 . According to the regression analysis, the data of this scale strongly depend on the indicators of the hysteria scale $(P$-value $=0.01)$. This indicates that expressing alcohol and the consequences of such abuse can make a person protesting, uncomfortable, and seeking to exaggerate their problems and attract attention. The results of the study confirmed the literature data about self-centered, depressive, and anxious fetures of addictive personality. We can assume that the higher the emotional lability, anxiety and depressive personality, the greater the likelihood of addiction to computer games. It is worth noting that this dependency is different from the other vivid virtual world, which gives the person the opportunity to hide in him from the troubles. For people with adaptation disorders and computer addiction, clinical manifestations of anxiety and depression, severe depressive and anxiety episodes are common; high levels of situational and personal anxiety, excessive nervous and mental stress. That is, we can conclude that both computer addiction and gaming addiction are strongly linked to anxiety and depression. We assume that these dependencies are very closely related and that it is difficult to draw a clear boundary. In addition to health problems, psychoactive substance use, and addiction to procedural addiction, it causes significant social and economic damage to individuals and society as a whole.

Keywords: addiction, addictive behavior, urgent dependence, psychoactive substances.

Эдуард Крайников, канд. психол. наук, доц.

Евгений Прокопович, канд. мед. наук, доц.

Киевский национальный университет имени Тараса Шевченко, Киев, Украина

Алёна Баланюк, психолог

Киев, Украина

\section{ОСОБЕННОСТИ АДДИКТИВНОЙ ЛИЧНОСТИ}

Мы исследовали 50 человек в возрасте 18-25 лет. Большинство респондентов являются студентами высших учебных заведений. Нами был использован такой психодиагностический инструментарий: СМОЛ (сокращенная адаптация ММРI), Методика диагностики копинг-стратегий Хейма, методика Менделевича, Мичиганский алкогольный тест (МАST), Опросник ургентной зависимости в адаптации Шибко. Респонденты демонстрируют некоторые признаки склонности, или даже четкого наличия аддиктивного поведения. Выбор способа ухода от реальности оказался явлением культурным, то есть выбор того или иного аддиктивного агента в большей степени продиктован рекламой, общественным мнением, продуктами искусства. Эти данные подтверждают плотную прямую связь алкогольной зависимости по опроснику MAST и психопатии - коэффициент корреляции составляет 0,27. По результатам регрессионного анализа, данные этой шкалы сильно зависят от показателей шкалы истерии (P-значение = 0,01). Это указывает на то, что прямо заявлять об употреблении алкоголя и наличии последствий такого злоупотребления может личность протестная, комфортная, и такая, которая стремится преувеличить свои проблемы, привлечь к себе внимание. Результаты исследования подтвердили имеющиеся в литературе данные о присущих аддиктам импульсивности, эгоцентричности, депрессивности и тревожности.

Ключевые слова: аддикция, аддиктивная поведеника, ургентная зависимость, психоактивные вещества.

Bulletin of Taras Shevchenko National University of Kyiv.

Series "Psychology". № 1(10), pp. 60-63 (2019)

УДК 159.9.016

DOI: https://doi.org/10.17721/BSP.2019.1(10).15
ISSN 1728-3817

(c) Taras Shevchenko National University of Kyiv,

Publishing Center "Kyiv University", 2019

Олена Литвиненко, канд. психол. наук, старш. викл. Київський університет імені Бориса Грінченка, Київ, Україна

\section{ПРАКТИЧНІ АСПЕКТИ РОБОТИ ПСИХОЛОГА 13 ВНУТРІШНЬО ПЕРЕМІЩЕНИМИ СТУДЕНТАМИ ПЕРШОГО КУРСУ}

Представлено концепцію комплексної психологічної адаптації першокурсників до студентського життя. Узагальнено теорії адаптивності юнаків і підлітків та концепції їх пристосування до нових умов життя й діяльності. Описано результати емпіричного дослідження індивідуально-психологічних якостей першокурсників, особливостей їх соціальної взаємодіі та академічної мотивації. Проаналізовано досвід психологічного супроводу процесу адаптації студентів, які є внутрішньо переміщеними, до навчання у ЗВО. Визначено їхні провідні особистісні та характерологічні особливості, способи пристосування до ситуації та реагування на несприятливі впливи із зовнішнього середовища. Окреслено перспективне коло досліджень у сфері психологічного супроводу та підтримки внутрішньо переміщених студентів.

Ключові слова: адаптація першокурсників, внутрішньо переміщені особи, адаптаційні ресурси, адаптаційний потенціал, навчально-виховний процес.

Постановка проблеми. Історичні процеси, що відбуваються в українькому суспільстві, зумовлюють появу значної кількості внутрішньо переміщених осіб - людей, які через військові дії на території їх рідних населених пунктів змушені були покинути власні домівки та розпочати нове життя на новому місці. Специфіка та тривалість адаптаційного періоду і призвичаєння їх до нових умов життя залежить від численних факторів: індивідуально-психологічних властивостей особистості, її адаптаційних ресурсів, особливостей функціонування емоційно-вольової сфрери, інтегрованості до суспільної та професійної діяльності, вікової категорії. Особливо травматичним адаптаційний період може стати для підлітків, у житті яких переміщення на нове місце проживання збігається зі вступом до вищого навчального закладу та початком студентського життя. Тому, принципового значення набуває цілеспрямована та організована робота різних спеціалистів (психологів, педагогів, кураторів та т'юторів), спрямована на інтеграцію таких підлітків у студентську спільноту та на елімінацію в них негативних виявів, пов'язаних із вимушеним переселенням. 
Аналіз досліджень і публікацій, в яких започатковано розв'язання проблеми. Попередній аналіз літератури показав, що існують численні спроби наукового тлумачення процесу адаптації підлітків та юнаків до навчання у вищому навчальному закладі. Так Ф. Б. Березін, В. В. Гриценко, Ю. О. Клейберг, П. С. Кузнєцов говорять про складність і багаторівневість процесу адаптації особистості до нових умов життя та діяльності [4]. Вступ до ЗВО традиційно пов'язаний з переходом до нової системи соціальної взаємодії. У першокурсників відбувається зміна традиційного способу життя, що автоматично запускає адаптаційні процеси. Своєю чергою, ці процеси пов'язані 3 вирішенням цілого спектра різноманітних проблем. Однією 3 центральних соціально-психологічних проблем процесу адаптації $€$ оволодіння новою соціальною роллю - роллю студента.

О. К. Гришанов та В. Д. Цуркан визначають адаптацію студента як процес приведення основних параматрів його соціальних і особистісних характеристик до відповідності, до стану динамічної рівноваги з новими вимогами середовища вищого навчального закладу, як зовнішнього фрактору щодо студента [5]. Т. І. Рогінська припускає, що адаптація студентів - це складний процес перебудови психічної діяльності, який повинен виявлятись у змінах рівневих значень окремих характеристик особистості та зміні взаємодії між ними, а також у різних співвідношеннях змін на різноманітних етапах адаптаційного процесу [4].

Своєю чергою, О.В. Сіомічев стверджує, що адаптація студентів-першокурсників пов'язана з подоланням труднощів входження до нового соціального середовища, установленням внутрішньогрупових взаємин, пристосуванням до нових форм навчальної діяльності.

О. В. Осипчукова виокремила чотири стадії адаптації особистості студента першого курсу, його навчальної групи до нового соціально-культурного середовища [5].

1. Початкова стадія. Індивід (група) усвідомлює, як необхідно поводитись у новому соціальному середовищі, але прийняти і визнати нову систему цінностей навчального закладу ще не готовий, тому намагається дотримуватись звичної системи цінностей.

2. Стадія терпимості. Між індивідом, групою та новим середовищем виникає взаємна терпимість до традиційних зразків поведінки й системи цінностей.

3. Акомодація. Прийняття та визнання індивідом системи цінностей у новому середовищі й одночасне визнання групою нового соціокультурного середовища цінностей індивіда.

4. Асиміляція. Збіг системи цінностей індивіда (групи) і середовища.

Отже, процес адаптації до навчання у ЗВО - це складна система перетворень, які відбуваються з людиною відповідно до змін умов існування. Початок студентського життя пов'язаний із чисельними соціальними змінами; заміною існуючих установок i стереотипів; стресовими ситуаціями. У деяких студентів це може призвести до підміни реального почуття дорослості такими діями, як свобода відвідування занять, несистематичне виконання домашніх завдань і т. п. Усе це може з часом трансоормуватись у небажання вчитись, відвідувати навчальний заклад та брати участь у його суспільному житті.

Такі кризові вияви в особливо гострій фоормі можуть спостерігатись у підлітків та юнаків, які не тільки змінили свій соціальний статус, вступивши на навчання до вищої школи, але й вимушені були покинути власну домівку через військові дії, які відбуваються у регіоні та пристосовуватись до нової діяльності в абсолютно нових умовах життя.
Адаптація внутрішньо переміщених студентівпершокурсників до навчання має проходити як активне творче пристосування студентів до умов ЗВО, у процесі якого у студентів фрормуються навички та вміння організації розумової діяльності, визнання обраної професії, раціональний особистий та колективний режим праці, відпочинку й побуту, система роботи із професійної самоосвіти та самовиховання професійно значущих якостей особистості.

Мета статті. Узагальнення практичного досвіду адаптації студетів першого курсу до навчання у 3ВО із зазначенням конкретних технік і технологій відповідної роботи зі студентами, які належать до категорії внутрішньо переміщених.

Викладення основного матеріалу. У межах заходів, спрямованих на знайомство зі студентамипершокурсниками ДВНЗ "Київський коледж легкої промисловості" та первинну їх адаптацію до навчання, нами було проведено комплексну діагностичну роботу. Загалом, діагностикою було охоплено 173 першокурсника, серед яких $24 \%$ мають порушення слуху, а $11 \% €$ внутрішньо переміщеними особами. Адаптаційні заходи відбувались за трьома основними напрямами:

1. Діагностика індивідуально-психологічних особливостей першокурсників, особливостей іх пізнавальної, емоційно-вольової та ціннісної сфери, специфіки налагодження міжособистісних взаємин та презентації себе зовнішньому світові.

2. Тренінгова робота 3 академічними групами та окремими підгрупами студентів.

3. Індивідуальне консультування за особистими зверненнями, на запит кураторів та викладачів, чи у відповідності до результатів психологічної діагностики.

Діагностика, як первинний етап установлення контакту зі студентами групи та збору їх психологічного анамнезу і психологічної профрілізації, проходила у три етапи. Перший, особистісно-орієнтований етап, відбувався у вересні та був орієнтований на виявлення індивідуально-психологічних особливостей студентів, їх цілей, цінностей, інтересів і прагнень. На другому етапі, який тривав у листопаді, було проведено діагностику специфіки міжособистісної взаємодії студентів у межах академічних груп, їх соціальної позиції та статусу. Третій етап проходив у другому семестрі першого навчального року та мав на меті діагностику мотиваційної сорери студентів, визначення основних параметрів їх академічної мотивації й дослідження способів подолання стресу, пов'язаного з навчальною діяльністю.

Крім очевидних цілей збору масиву даних та створення психологічних профілів студентів, така діяльність (особливо на початку навчального року) мала на меті самопрезентацію практичного психолога, установлення довірчих стосунків зі студентами, а також психологічну просвіту, тобто підвищення рівня знань студентів про специфіку роботи психолога і пробематику, з якою до нього можна звернутись. Результати діагностики повідомлялись кожному студенту індивідуально, а в узагальненому вигляді були надані кураторам академічних груп.

Взаємодія 3 кураторами - це окремий важливий етап у роботі психолога, спрямований на адаптацію першокурсників. Для продуктивної діяльності зі згуртування групи й організації позанавчальної діяльності першокурсників куратор має бути проінформований про індивідуальні властивості, риси та якості студентів своєї групи. Це дозволяє максимально ефективно інтегрувати їх до студентського життя ЗВО.

За результатами психологічної діагностики студентів за допомогою Індивідуально-типологічного опитува- 
льника (Л. М. Собчик) було виявлено, що всім студентам, які належать до категорії внутрішньо переміщених, властиві високі показники за шкалою агресивності та підвищені показники сензитивності й емотивності. Це свідчить, що спільним для таких студентів $€$ прагнення до самоствердження, активність і самостійність у поєднанні з емоційною нестійкістю, вразливістю та схильністю до депресивних реакцій на невдачі. За іншими шкалами методики статистично значущіх збігів виявлено не було.

Розподіл результатів дослідження внутрішньо групової взаємодії відповідає кривій нормального розподілу, тобто $27 \%$ таких студентів мають високий соціометричний статус у своїх академічних групах; статус $20 \%$ є низьким і 53 \% мають соціометричний статус, який може бути охарактеризований як середній. Ця тенденція спостерігається і при аналізі результатів усіх досліджуваних першокурсників.

Лонгитюдне спостереження за груповою динамікою в середині академічних груп дало змогу констатувати той факт, що переважна більшість студентів, які $є$ внутрішньо переміщеними, на перших етапах міжособистісної взаємодії намагались зайняти адміністративні посади в академічних групах (стати старостою, заступником старости, профоргом і т. п.). Це свідчить про наявність у них таких спільних рис, як цілеспрямованість, амбіційність, прагнення до лідерства.

Проте, посівши обрані посади доволі легко, більше половини з них (60 \%) дуже швидко втратили інтерес до суспільно-громадської роботи та перестали виявляти необхідну ініціативу. Результатом цього стало те, що до кінця навчального року всі вони були зміщені зі своїх посад. 3 іншого боку, останні 40 \% виявили здібності до адміністративно-організаторської діяльності та досягли успіхів не лише на рівні академічної групи, але й були включені до суспільної діяльності навчального закладу: вступили до студради, активу студентської профспілки, стали брати активну участь у волонтерській та благодійній діяльності.

На третьому етапі психологічної діагностики відбувалось визначення структури і рівня академічної мотивації першокурсників. Дослідження проводилось у лютому - березні, коли студенти вже склали першу сесію, стикнулися з першими труднощами та познайомились із рейтинговою системою призначення стипендії, що стало для них додатковим фрустраційним фактором. Відповідно до чинного законодавства, студенти, які $\epsilon$ внутрішньо переміщеними особами, можуть не брати участі у рейтинговій гонці та, у випадку позитивного завершення заліково-екзаменаційної сесії, за будь-яких умов отримують соціальну стипендію. 3 нашого погляду, це $є$ принциповим фрактором впливу на їхню академічну мотивацію.

Як діагностичний інструмент було використано Шкалу академічної мотивації (The Academic Motivation Scale). За її допомогою було виявлено таку тенденцію: для всіх студентів із категорії переміщених характерним $\epsilon$ високий і дуже високий рівень екстернальної мотивації, тобто в їхньому випадку - необхідність навчальної діяльності, обумовлена вимогами соціуму; навчання відбувається переважно для того, щоб запобігти виникненню будь-яких проблем.

Крім того було проаналізовано академічну успішність таких студентів. Усі вони демонструють навчальні показники середнього і високого рівня. $20 \%$ із них навіть були включені до загального стипендіального рейтингу, тобто увійшли до $45 \%$ найуспішніших студентів своєї спеціальності.
Загалом, аналізуючі результати діагностики адаптованості студентів першого курсу, зокрема тих, які $є$ внутрішньо переміщеними, до навчання у ЗВО можна стверджувати, що всі вони є доволі амбіційними, налаштованими на досягнення лідерських позицій, відкритими для соціальної активності, яка служить для них певним заміщуючим фактором, що компенсує втрату звичного кола соціальної взаємодії.

У межах другого адаптаційного напряму роботи проводились групові тренінгові заняття з першокурсниками, метою яких було знайомство їх один із одним та інтеграція до групової активності. Критеріями ефективності тут виступили рівень згуртованості академічних груп та відчуття психоемоційного комфорту в ситуаціях навчання. Крім того, було проведено цикл занять з елементами тренінгу "Вчимося ефективно вчитися", метою яких став розвиток у студентів навичок самоорганізації та конструктивної навчальної діяльності.

Студенти, які $€$ внутрішньо переміщеними, активно включалися у тренінгову роботу, намагаючись отримати якомога більше уваги психолога. А, налагодивши робочій контакт із психологом і відчувши довіру до нього, почали записуватись на особисті консультації. Цікавою є така статистика: серед студентів перших курсів протягом навчального року на індивідуальну консультацію до психолога записались $19 \%$ осіб. 3 іншого боку, кількість внутрішньо переміщених студентів, які усвідомили необхідність психологічної допомоги та звернулись до неї, становить 70 \%. Тобто, попри зовнішню стійкість та нормальну адаптованість до навчання і студентського життя, вони переживають кризові стани, 3 якими не можуть упоратись самостійно.

Традиційними причинами звернення першокурсників до психолога є такі: відчуття беззмістовності життя й депресивний настрій; проблеми у взаєминах із одногрупниками; конфлікти із близькими людьми; труднощі у стосунках із представниками протилежної статі; небажання вчитись і труднощі стосовно засвоєння матеріалу; конкретні окремі страхи та тривоги; прагнення до саморозуміння й самоаналізу; бажання привернути до себе увагу та бути почутим тощо.

Завданням психолога при цьому стала емоційна підтримка та фрасилітація студентів, елімінація інтенсивності невротичних виявів, розвиток навичок міжособистісної взаємодії та пошук особистісних ресурсів. Загалом, процес адаптації першокурсників можна вважати успішним. Протягом навчального року та по його закінченню жоден студент не був відрахований через заборгованості у навчанні, або конфлікти з одногрупниками; переважна більшість студентів була інтегрована до позанавчальної діяльності та різних видів соціальної активності.

Висновки. Актуальним питанням сучасної вітчизняної психології $€$ теоретичне осмислення і конкретне емпіричне вивчення адаптації внутрішньо переміщених студентів до навчання у ЗВО.

Адаптація до навчання - це комплексний процес засвоєння норм і правил навчального закладу, налагодження дружніх відносин із одногрупниками та конструктивних взаємин із викладачами; вироблення стратегій навчальної діяльності та позаначальної активності.

У межах проведеної нами діагностики адаптованості студентів першого курсу ДВНЗ "ККЛП" до навчання, було виявлено, що ті з них, хто належить до категорії внутрішньо переміщених осіб у цілому демонструють нормальні показники включеності до навчального процесу і студентського життя. 3 іншого боку, вони значно більшою мірою, ніж інші студенти потребують безпосередньої уваги та допомоги психолога. Індивідуальна робота із психологом дозволяє їм подолати стрес, пов'язаний зі зміною умов життя і звичного кола соціальної взаємодії та зняти 
психоемоційну напругу, пов'язану 3 неможливістю довгострокового планування (через невизначеність майбутніх умов життя).

Перспективу подальшої діяльності у цьому напрямі ми вбачаємо у розробці чіткого і структурованого алгоритму надання консультаційної та психокорекційної допомоги таким студентам. Це полегшить роботу практичних психологів та інших фахівців, які опікуються соціально-психологічною адаптацією першокурсників до умов студентського життя.

\section{Список використаних джерел}

1. Березовин Н. А. Адаптация студентов к жизнедеятельности вуза: психолого-педагогические аспекты / Н. А. Березовин // Выбраныя науковыя працы БДУ. - Минск, 2001. - С. 11-25.

2. Лазос Г. П. Психологічна допомога внутрішньо переміщеним особам (на прикладі роботи з переселенцями з Криму) / Г. П. Лазос // Психологічна допомога постраждалим унаслідок кризових травматичних подій : метод. посіб. - Київ : ТОВ "Видавництво "Логос", 2015. - 206 с.

3. Психологическая помощь мигрантам: травма, смена культуры, кризис идентичности / под ред. Г. У. Солдатовой. - Москва: Смысл, 2002. -479 c.

4. Смаль В. Внутрішньо переміщені особи: соціальна та економічна інтеграція в приймаючих громадах / В. Смаль // Дослідження проекту міжнародної технічної допомоги "Партнерство для розвитку міст" [Електронный ресурс]. - Режим доступу: http://pleddg.org.ua/wpcontent/uploads/2016/05/IDP_REPORT_PLEDDG_edited_09.06.2016.pdf.

5. Чикина Т. Е. Адаптивное обучение первокурсников / Т. Е. Чикина. [Электронный ресурс]. - Режим доступа: http://vovr.ru/upload/6-09.pdf.

6. Шлаина В. М. Адаптация первокурсников к учёбе в ВУЗе / В. М. Шлаина // Менеджмент и кадры: психология управления, соционика и социология. - 2013. - № 2. - С. 28-30.

7. Miller K. Rethinking a Familiar Model: Psychotherapy and the Mental Health of Refugees / K. Miller // Journal of Contemporary Psychotherapy. 1999. - Vol. 29. - No. 4.- P. 283-306.

8. Kristal-Andersson B. Psychology of the refugee, the immigrant and their children: Development of a conceptual framework and application to

Olena Lytvynenko, PhD, Senior Lecturer

Boris Grinchenko University of Kyiv, Kyiv, Ukraine psychotherapeutic related support work / B. Kristal-Andersson. Department of Psychology, University of Lundt, 2000. - $370 p$

9. Burke S. Psychological First Aid. An Australian guide to supporting people affected by disaster [Electronic resource]. - Access mode: http://www.redcross.org.au/files/Psychological_First_Aid_An_Australian_Guide.pdf

\section{References}

1. Berezovyn N. A. Adaptatsyya studentov k zhyznedeyatel'nosty vuza: psykholoho-pedahohycheskye aspekty // Vybranyya naukovyya pratsy BDU. - Mynsk, 2001. - S. 11-25.

2. Lazos H. P. Psykholohichna dopomoha vnutrishn'o-peremishchenym osobam (na prykladi roboty z pereselentsyamy z Krymu). Psykholohichna dopomoha postrazhdalym vnaslidok kryzovykh travmatychnykh podiy metod. posibnyk. - Kyiv : TOV "Vydavnytstvo "Lohos", 2015. - 206 s.

3. Psykholohycheskaya pomoshch' myhrantam: travma, smena kul'tury, kryzys ydentychnosty/Pod red. H. U. Soldatovoy. - Moskva: Smysl, 2002. $-479 \mathrm{~s}$.

4. Smal' V. Vnutrishn'o-peremishcheni osoby: sotsial'na ta ekonomichna intehratsiya $v$ pryymayuchykh hromadakh. Doslidzhennya proektu mizhnarodnoyi tekhnichnoyi dopomohy "Partnerstvo dlya rozvytku mist", [Elektronnyy resurs]. Rezhym dostupu: http://pleddg.org.ua/wpcontent/uploads/2016/05/IDP_REPORT_PLEDDG_edited_09.06.2016.pdf.

5. Chykyna T. E. Adaptyvnoe obuchenye pervokursnykov. [Elektronnyy resurs]. Rezhym dostupa: http://vovr.ru/upload/6-09.pdf.

6. Shlayna V. M. Adaptatsyya pervokursnykov $k$ uchëbe $v$ VUZe. Menedzhment y kadry: psykholohyya upravlenyya, sotsyonyka y sotsyolohyya. - 2013. - № 2. - S. 28-30.

7. Miller K. Rethinking a Familiar Model: Psychotherapy and the Mental Health of Refugees // Journal of Contemporary Psychotherapy. - Vol. 29. No. 4, 1999. - Pp. 283-306.

8. Kristal-Andersson B. Psychology of the refugee, the immigrant and their children: Development of a conceptual framework and application to psychotherapeutic related support work // Department of Psychology, University of Lundt, 2000. - 370 p.

9. Burke S. Psychological First Aid. An Australian guide to supporting people affected by disaster [Electronic resource]. Access mode: http://www.redcross.org.au/files/Psychological_First_Aid_An_Australian_Guide.pdf. Надійшла до редколегії 12.05.19

\section{PRACTICAL ASPECTS OF PSYCHOLOGICAL WORK WITH INTERNALLY DISPLACED FIRST-YEAR STUDENTS}

The concept of complex psychological adaptation of first-year students for student life is presented. Theories of adaptability of adolescents and adolescents and the concept of their adaptation to new minds of life and activity are generalized. The results of the empirical study of the individual-psychological qualities of the freshmen, the features of their social interaction and academic motivation are described. The experience of the psychological support of the process of adaptation of students who are internally displaced to study at a university is analyzed. Their true personal and character peculiarities, ways of adapting to the situation and responding to adverse influences from the external environment are determined. The perspective circle of researches in the field of psychological support and support of internally displaced students is outlined. Adaptation to learning has been found to be a complex process of learning the norms and rules of an educational institution, forging friendships with one-groupers, and for constructive relationships with teachers; development of strategies of educational activity and initial activity. The article determines that the adaptation of internally displaced first-year students to study should come as an active tertiary adaptation of students to the higher education institutions, in the process of developing students'skills and ability to organize their understanding, and life, the system of working with professional self-education and self-education of professionally significant qualities of personality. It has been found that the process of adaptation to university education is a complex system of transformations that occur with a person in accordance with changes in the minds of existence. The beginning of a student's life is connected with numerous social changes; replacement of existing attitudes and stereotypes; stressful situations. For some students, this can lead to the substitution of a real sense of adulthood by activities such as freedom to attend classes, unsystematic homework, and so on. All of this can, over time, be transformed into a reluctance to study, attend a school, and participate in one's social life.

Key words: adaptation of first-year students, internally displaced people, adaptive resources, adaptive capacity, educational process.

Елена Литвиненко, канд. психол. наук, старш. преподаватель Киевский университет имени Бориса Гринченко, Киев, Украина

\section{ПРАКТИЧЕСКИЕ АСПЕКТЫ РАБОТЫ ПСИХОЛОГА С ВНУТРЕННЕ ПЕРЕМЕЩЕННЫМИ СТУДЕНТАМИ ПЕРВОГО КУРСА}

Представлена концепция комплексной психологической адаптации первокурсников к студенческой жизни. Обобщены теории адаптивности юношей и подростков, а также концепции их приспособления к новым условиям жизни и деятельности. Описаны результаты эмпирического исследования индивидуально-психологических качеств первокурсников, особенностей их социального взаимодействия и академической мотивации. Проанализирован опыт психологического сопровождения процесса адаптации внутренне перемещённых студентов к учёбе в вузе. Определены их ведущие личностные и характерологические особенности, способы приспособления к ситуации и реагирования на неблагоприятные события внешнего мира. Очерчен перспективный спектр исследований в сфере психологического сопровождения и поддержки внутренне перемещённых студентов.

Ключевые слова: адаптация первокурсников, внутренне перемещённые лица, адаптационные ресурсы, адаптационный потенциал, учебно-воспитательный процесс. 